\title{
ON DIFFERENTIAL OBJECT MARKING IN SOUTHERN AND CENTRAL SELKUP
}

\author{
Hannah Wegener \\ University of Hamburg
}

\begin{abstract}
The phenomenon of differential object marking has been investigated for a number of languages of the world. Studies have been carried out for individual languages as well as from a typological point of view. It is broadly described as an alternation in case marking of the direct objects. Triggers for the case alternation can be the referent's animacy, information structure, modus, and definiteness among others. In the present study data from Central and Southern Selkup are investigated with respect to case marking of nominal and pronominal direct objects. Nominal direct objects exhibit instances of accusative and nominative marking while the latter show consistent accusative marking. Analyzing the contributing factors for the different kinds of case marking, imperative mood appeared to have an impact, the information status as well as structural properties of the object, i.e. whether it is part of a direct object phrase or coordination. Possessive direct objects behave similar in that they are mostly in accusative and only occasionally nominative marked. As opposed to the non-possessive direct objects, no variation in information status can be registered.
\end{abstract}

Keywords: argument marking, differential object marking, Uralic languages, Samoyedic, Selkup, syntax

DOI: https://doi.org/10.12697/jeful.2018.9.1.07

\section{Introduction}

\subsection{The notion of differential object marking}

The phenomenon of differential object marking, henceforth DOM, has first been researched systematically by Georg Bossong (1985) who defined it as "[...] special [...] marking of animate and/or definite accusative-objects [...] (Bossong 1985: 3). The characteristics of definiteness and animacy are resumed by Aissen (2003) in a functional typological approach of DOM based on Harmonic Alignment. Direct objects therefore are case marked depending on their prominence which is defined by their referent's animacy and definiteness. She states "the 
more prominent a direct object, the more likely it is to be overtly case marked" (Aissen 2003: 436). In matching hierarchies of definiteness and animacy with the relational scale, typical subject and object properties show. For subjects these are human, definite and a typical topic whereas typical objects are inanimate and indefinite. The case marking of arguments ensures a maximal differentiation of subjects and objects. This leads to the so called markedness reversal. "[...] What is marked for objects is unmarked for subjects and vice versa [...]" (Aissen 2003: 438). This markedness reversal however has received criticism by Næss (2004) in that the subject-object opposition is not backed up by language data. More likely the relation between subjects and objects is being affected by the verbal constituent to different degrees. Unmarked subjects are unaffected because they are in control of the action while an unmarked object is affected as it is controlled by the verbal constituent. Accusative languages therefore emphasize the affectedness of direct objects in marking them differently. Thus the opposition is one of control and affectedness. Ergative systems on the other hand mark control and therefore the participant in control of the action. Instead of an inherent opposition between subject and object the context seems crucial in defining the relation (Næss 2004: 1210-1211).

From a typological point of view definiteness and animacy do not universally influence DOM (Sinnemäki 2014). Semantic-pragmatic characteristics in general were observed to have only very little impact on grammatical patterns, although this aspect is highly language specific. Throughout languages that morphologically mark case, DOM is the preferred system. Sinnemäki defines DOM as differences in marking direct objects triggered by factors such as TAM, animacy, definiteness, information structure, kinship terminology, as well as the differentiation between nouns and proper nouns. One factor or a combination of such may be responsible for differences in direct object marking. In languages operating with information structure topicality proved to be a critical factor (Sinnemäki 2014).

\subsection{The Selkup language}

The Selkup language belongs to the Samoyedic branch of the Uralic language family. Its linguistic territory is distributed throughout an area between the rivers $\mathrm{Ob}$ and Yenissei in Northwest-Siberia. According to Gluškov et al. (2013) Selkup can be divided into three dialectal groups, Northern, Central and Southern Selkup with no mutual understanding 
between the groups. Older descriptions name a fourth variety, namely Ket Selkup (cf. Helimski 1998). Gluškov et al. however, include Ket Selkup into the Southern dialectal group. Regarding the linguistic situation Selkup has largely been replaced with Russian. The Northern dialectal group counts a number of native speakers. The Central and Southern dialects however can be regarded as on the verge of extinction (Helimski and Nagy 2004).

Selkup is an agglutinative language with a rather rich case system and verbal morphology. The Central and Southern dialects are not well described. The grammar of Bekker et al. (1995) is the first detailed description of Southern Selkup. For direct objects accusative case is postulated as well as nominative. A more recent description regarding the Central and Southern dialects is presented by Bykonja et al. (2005: 318-336) as part of a Selkup-Russian dictionary. While the nominative is expressed with zero marking, for the accusative case two forms exist, $-m$ and $-p$. Both can be used interchangeably without altering the meaning. In addition, the suffix $-m$ occurs in possessive direct object NPs of the first person singular (Bykonja et al. 2005: 327-328).

\subsection{Preliminary studies on Selkup}

In line with typological accounts of DOM such as the one by Aissen (2003), animacy and definiteness have to be considered for the analysis of Selkup. While animacy does not pose a problem, definiteness as a criterion for Selkup may lead to difficulties as the language lacks determiners, and the exact ways of marking definiteness have yet to be researched. In his attempt of describing the object argument in the Uralic languages Wickman (1955) evaluates language material collected by M.A. Castrén and Grigorij Prokof'ev. The data shows no differentiation between dialectal groups. Both Castrén and Prokof'ev have noticed an alternation between accusative and nominative marking in direct objects. Wickman distinguishes three different groups of direct objects, according to their case marking. The first group contains those objects occurring with imperative verbs of the second person, and marked nominative. The second group consists of direct objects which are attributed a cardinal number and are marked nominative as well. The third group includes all accusative objects. The conditions imperative mood and quantification as triggers for nominative marking are, however, not reliable, as Wickman notes. The overall tendency in Selkup is to mark direct 
objects with accusative case (Wickman 1955). Unmarked, i.e. nominative, objects in the Uralic languages have also been addressed by Havas (2008). Concerning Selkup he seeks to establish a connection between case marking and definiteness. For the Northern Selkup dialectal group the differing case marking for direct objects and its influencing factors has been further described by Helimski (1998) and Kuznecova et al. (1980). It is postulated "that the direct object is [...] always in the nominative, if the verb is in the imperative, and [...] predominantly in the nominative, if the object is indefinite; but [...] predominantly in the accusative, if the object is definite, and [...] always in the accusative, if the object is a personal pronoun" (Helimski 1998: 576).

Detailed accounts of DOM within the Uralic languages have further been presented, for example for the Ob-Ugric language Mansi (Skribnik 2001, Virtanen 2014), the Samoyedic language Nenets (Dalrymple and Nikolaeva 2011) and the Permic language Komi (Klumpp 2014). In addition, differential marking of direct objects is described for Mordvin (Lewy 1933) and Southern Saami (Itkonen 1972).

\section{Data and Method}

The present study is a corpus based study. It is an attempt at identifying the pattern of direct object marking in the two dialectal groups of Central and Southern Selkup.

\subsection{The corpus}

The corpus used for the analyses is a sub-corpus of the corpus of Central and Southern Selkup which is currently compiled in an ongoing project $^{1}$. The data consists of transcribed folklore texts originally narrated by two speakers of Central and Southern Selkup between the years 1980 and 1983. Both speakers are female and were born between the years 1923 and 1915. The Central Selkup speaker was born in Vol'dža while the Southern Selkup speaker is from Kijarovo. Altogether six texts are analyzed - three of each dialectal group. With an overall number of 375 utterances and 2225 tokens the corpus is rather small in size. Both dialectal groups are represented approximately equally,

1 The compilation of the corpus is part of the DFG-funded project Syntactic description of Southern and Central Selkup dialects: a corpus-based analysis (WA 3153/3-1). 
with a slight imbalance in favor of Central Selkup. The Central Selkup data counts 186 sentences and 1128 tokens, and the Southern Selkup component numbers 189 utterances and 1097 tokens. All six texts have been previously published in the Annotated Folklore Prose Texts of Ob-Yenissey Language Area (Bajdak et al. 2010), and Annotated Folk and Daily Prose Texts in the Languages of Ob-Yenissey linguistic Area vol. 2 (Bajdak et al. 2012) and vol. 3 (Bajdak et al. 2013).

\subsection{Method}

In a first step the overall number of direct objects for both dialectal groups, including possessives but not yet counting them separately, was determined. Then, in a subsequent query nominal direct objects and nominal human direct objects were identified. The same has been done for pronominal direct objects, i.e. searching for pronominal and pronominal human direct objects as they are annotated separately and therefore need to be searched for independently.

Once the objects had been treated quantitatively, a qualitative analysis followed. In order to do so the case marking of every direct object was analyzed and the objects were grouped accordingly. Thus establishing 5 categories of direct objects:

- accusative marked

- nominative marked

- accusative possessively marked

- nominative/accusative possessively marked

- nominative possessively marked

Since the accusative is regarded as the standard marker for direct objects in Selkup, instances of nominative and possessive marking were further investigated and checked against previous accounts of direct object marking in Selkup. Furthermore, the cross-linguistic factors information status, degree of activation, animacy, and verb inherent characteristics such as imperative mood were taken into account, as they have been observed to be an influencing factor in DOM (Sinnemäki 2014).

The analysis was performed with respect to both dialectal groups, in order to observe possible differences in their treatment of direct objects. 


\section{Results}

The overall number of direct objects amounts up to 179 . With a share of 149 , the majority of objects are expressed by an NP $(83 \%$ of the total instances), while pronominal direct objects (30 instances) only make up to $17 \%$. Figure 1 presents an overview of the general distribution of direct object expressions throughout the corpus, stratified by dialectal group.

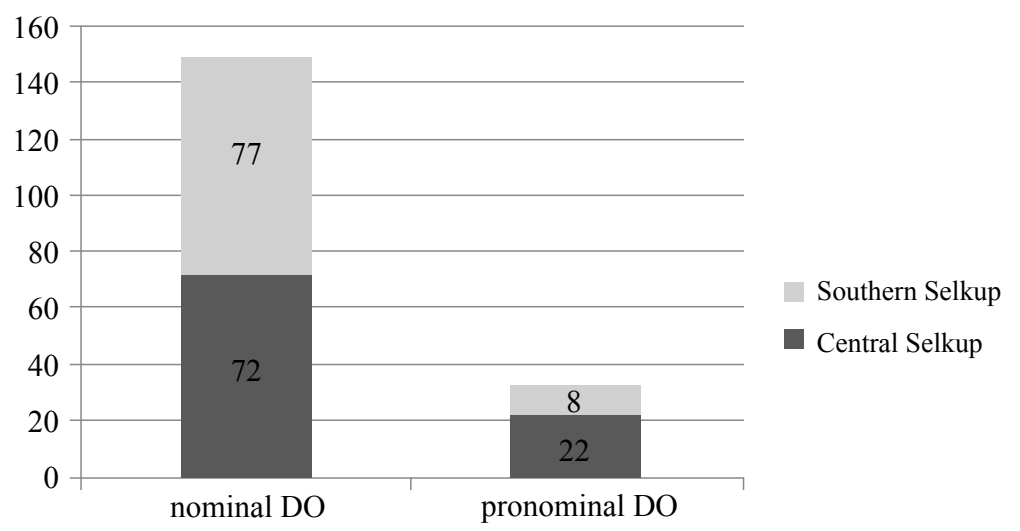

Figure 1. Overall distribution of direct objects

\subsection{Pronominal direct objects}

Pronominal direct objects consistently occur in their accusative form regardless of their dialectal group or animacy. Notably, even in combination with imperative mood the case does not change, unlike nominal direct objects (cf. example 2+12).

(1) Central Selkup (ChDN_1983_MistressOfFire_flk.019)

Mat šindi po:ye awdimbak.

mat šindi po:-ze aw-di-mba-k

$1 \mathrm{SG}$ 2SG.ACC tree-INS eat-TR-RPST-1SG

'I fed you with wood.'

The referent of the personal pronoun in 2SG.ACC is already mentioned in the sentence before (1). The woman scolds the fire and asks 'what do you do?', which means, that the information status for the pronominal direct object is given and active. 
To compare with a pronominal direct object occurring with an imperative, consider example (2). It is part of the same tale as the sentence in example (12) below, thus the similarity.

(2) Central Selkup (ChDN_1983_GirlAndIce_flk.006)

ära čenča: «ulyo, mażk tan üdìs, mat t'ekka n'em m'ellage!»

ära čenča ulyo mazik tan üdi-š mat

old.man say.3sg ice 1sG.ACC away let.go-IMP.2sG 1sG

t'ekka n'e-m m'e-lla-ge

2SG.DAT daughter-NOM/ACC.1SG give-OPT-1SG

'The old man says: «Ice, let me go, I will give you my daughter».'

Even though the imperative mood can influence the case marking for nominal direct objects, pronominal direct objects seem unaffected. With regards to information status, the referent is given and active as he is the one speaking and has been mentioned in the first sentence of the tale.

\subsection{Nominal direct objects}

Nominal direct objects mostly appear in the accusative case. In general, 130 accusative direct objects have been identified, counting accusative bare nouns as well as accusative objects with possessive marking. 61 instances occurred in the Central Selkup part of the corpus and 69 in the Southern Selkup section. Nominative marked direct objects occurred with a total of nine; two of them in Central and seven in Southern Selkup.

(3) Central Selkup (ChDN_1983_TaleBrownies_flk.014)

Kuзakkit tab mad'onde kwenguk, na nel qup, tab t'ärba qajl'emil fa hurup kwatku.

kuza-kkit tab mad'o-nde kwen-gu-k na ne-1

when-LOC 3sg taiga-ILL go.away-ITER-3sg this woman-ADJZ

qup tab t'är-ba qaj-1'-em-i-1 fa

person 3sG think-RPST.3SG what-ADJZ-INDEF-EP-ADIZ good

hurup kwat-ku

wild.animal kill-INF

'When she is going in the forest, this woman thinks about killing some good animals.' 
Sentence (3) exemplifies an instance of nominative marked direct object. Particularly in this sentence, however, the referent is part of an object phrase which may be the reason for the lack of accusative marking. In terms of information status, the referent has never been mentioned before. It occurs, though, in a context of hunting as part of a description of the Selkups' way of living alongside little wooden goblins and going into the taiga to hunt animals.

(4) a. Central Selkup (ChDN_1983_MistressOfFire_flk.088)

Šiw po:ne wes' qadolbap tuye taq čuball'eb'e.

$\begin{array}{lllll}\text { Šiw po:ne } & \text { wes' } & \text { qado-l-ba-p } & \text { tu-ye } & \text { taq } \\ \text { ashes outward(s) } & \text { all } & \text { scratch-INCH-RPST-1sG } & \text { wing-INSTR } & \text { away } \\ \text { čubal-l'e-b'e } & & & & \\ \text { sweep-OPT-1sG.OBJ } & & & & \end{array}$

'I rake off all the ashes, I sweep them in a sway.' (translation HW)

In (4a) the word šiw 'ashes' is in the nominative case. It appears in combination with wes' 'all', a Russian loan word functioning as a quantifier. It could be assumed that it is the quantifier that determines the nominative case. The preceding sentence contradicts this claim, in that it contains a quantified direct object, which is marked accusative. To compare:

(4) b. Central Selkup (ChDN_1983_MistressOfFire_flk.087)

Mat hel'd' po:p pažekap.

mat hel'd' po:-p paže-ka-p

$1 \mathrm{SG}$ seven tree-ACC chop-ITER-1SG.OBJ

'I chop seven logs.'

The context of the utterance is a woman talking about living in a house and owning a stove. Subsequently sentence (4b) about chopping seven logs is uttered, directly followed by (4a). The referent šiw 'ashes' is therefore not new, but rather accessible-inferable as it forms a partwhole relationship with the stove. Throughout the corpus three direct objects quantified by wes' occurred, all of them marked nominative. 
(5) Southern Selkup (SEV_1980_HazelGrouse_flk.029)

Tab ma:t šrrle t’u:ra, i:qind ə:亏̌algwa: " qaj tat me:mmindal?

Tap ma:t šcr-le t'u:-r-a i:-qind

3SG house go.into-CVB cry-FREQ-AOR.3SG son-DAT/ALL.3SG

ә:з̆a-l-gw-a qaj tan me:-mmi-nda-1

Say-INCH-ITER-EP what 2SG do-HAB-INFER-2SG.OBJ

'She went into the house crying, said to her son: What have you done?'

In sentence (5) it is the expression ma:t 'house' that receives nominative case. The direct object is an argument of a converb construction.

Preceding this sentence, the family's horse had come home dragging behind the husband on a sled chopped into pieces. In this context, the referent of ma:t is accessible.

\subsection{Nominal direct objects in possessive}

Possessively marked direct objects occurred in the corpus in three groups. The first group consists of possessive direct objects that received accusative case. The second group contains those possessive direct objects marked nominative, and in the third group direct objects were marked possessively but the nature of case marking remains unclear.

\subsubsection{Accusative possessive}

Possessive direct objects in accusative occur altogether 24 times. Out of these, 12 can be allocated to Central Selkup and 12 to the Southern variety. The Central Selkup instances are all in 3rd person singular, meaning the possessee is $3 \mathrm{SG}$, as can be seen in (6).

(6) Central Selkup (ChDN_1983_ItjaStayedAlone_flk.012)

kwilšanimdì weškahe tìrale penbadi, uguľ̌e üppidigu takkilimbay

(lakkimbay).

\begin{tabular}{|c|c|c|}
\hline kwilšan-i-m-di & wešk-a-he & tira-le \\
\hline boat-EP-ACC-3SG & cedarwood.cone-EP-INS & fullness-ADJZ \\
\hline pen-ba-di & ugulక̌e üppi-di-gu & takki-li-mba-y \\
\hline put-RPST-3DU.OBJ & home begin-IPFV-INF & collect-RES-RPST-3DU \\
\hline $\begin{array}{l}\text { lakki-mba-y } \\
\text { want-RPST-3DU }\end{array}$ & & \\
\hline
\end{tabular}

'They fill the boat with cones, they wanted to go home.' 
Utterance (6) depicts an inanimate referent, which is marked accusative in addition to $3 \mathrm{rd}$ person singular. The information status of the referent of kwilšanimdi is given, but inactive. The boat had been introduced to the context three sentences before.

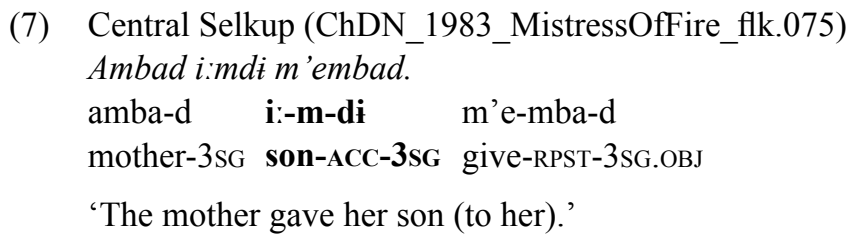

As (7) shows, accusative is applied to possessive direct objects regardless of their animacy: $i:-m-d i$ is a human referent, but receives the same treatment as kwilsanimdi in (6). The number of the possessor is also 3rd person singular, as is the case with the inanimate referents. In the sentence directly preceding (7) the mother was prompted to hand over her son. Hence the information status of the referent 'son' is given and active.

\section{(8) Southern Selkup (SEV_1980_HazelGrouse_flk.030) Azemd pad'albat. aze-m-d pad'a-1-ba-t father-ACC-3SG chop.off-INCH-RPST-3SG.OBJ \\ 'Father has been hacked to death' (translation HW)}

For Southern Selkup no inanimate possessive direct objects with accusative marking have been found in the corpus. (8) exemplifies that for Southern Selkup the same is true as it is for Central Selkup. Possessive direct objects can be marked accusative and make out the largest group. Before sentence (8), the father is mentioned in form of 'husband'. Thus 'father' in this sentence poses a given, albeit inactive, referent.

\subsubsection{Nominative possessive}

Possessive direct objects in nominative form occur far less often than accusative ones. Two have been identified for Central Selkup and one for the Southern dialectal group, giving three in total. 
(9) Central Selkup (ChDN_1983_MistressOfFire_flk.074)

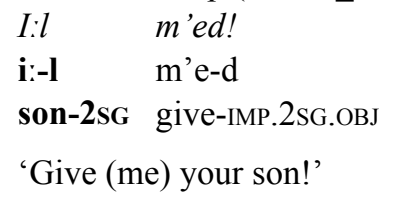

The direct object in (9) is animate and in 2 nd person singular. It is also the argument of a verb in imperative mood. The referent 'son' has been first introduced eight sentences before (9). It has been kept active in two following utterances and then dropped. It was once reactivated in form of an NP 'boy' three sentences before (9), but dropped again. Eventually the referent 'son' has been picked up again in what is example sentence (9) here and is therefore given-inactive.

(10) Southern Selkup (SEV_1980_HazelGrouse_flk.064)

Natide:li tö:mbat, awit i:ndse qwedeld'at.

natide:li tö:-mba-t awi-t i:-n-d-se

there come-RPST-3PL mother-3sG Son-GEN-3SG-COM

qwede-l-d'a-t

meet-INCH-IPFV-3PL

'They came, met the mother and the son.'

The referent in (10) is human and possessively marked, however it is part of a coordinative construction consisting of mother in 3rd person singular and son in genitive, 3rd person singular and comitative. Concerning the information status, the referent of 'mother' was introduced in the first sentence of the tale as 'old woman'. Although not mentioned very often, the referent is given and, because it has not been uttered directly before example sentence (10), inactive.

\subsubsection{Nominative/accusative possessive}

Direct objects in this group are marked with $-m$, which could mean either accusative or possessive marking in 1st person singular, as both the 1st person singular as well as accusative marker is $-m$. Another possibility is an assimilation process of the two forms resulting in only one form carrying both functions. The sentences are ambiguous, so no definite decision can be made as to what kind of marking is present. Overall, four of these instances could be identified. All of them stem from the Central Selkup part of the corpus. 
(11) Central Selkup (ChDN_1983_MistressOfFire_flk.063) Tab man wandom ped'e pad'assit.

Tab man wando-m ped'-e pad'as-si-t

3SG 1SG face-NOM/ACC.1sg axe-INSTR cut-PST-3SG.OBJ

'She cut my face with an axe.' (translation HW)

The personal pronoun of the 1 st person singular preceding the direct object in (11) hints at a possessive meaning of wando- $m$. The morphological glossing alone is ambiguous. In (11), 'face' forms a part-whole relationship with the speaker and is accessible-inferable.

(12) Central Selkup (ChDN_1983_GirlAndIce_flk.008)

ära üčega n'emd t'an'etemba m'egu: «ulyo, mażn tan üdeš, man üčega n'em t'ekka mellage!»

ära üčega n'e-m-d t'an'e-te-mba m'e-gu ulyo

old.man small daughter-ACC-3SG mind-DRV-RPST.3SG give-INF ice

mazin tan üde-š man üčega n'e-m

1SG.ACC away let.go-IMP.2SG $1 \mathrm{sG}$ small daughter-NOM/ACC.1sG

t'ekka me-lla-ge

2SG.DAT give-OPT-1SG

'The old man decided to give his younger daughter away: Ice, let me go, I will give you my younger daughter!'

In the example above the referent is human, but treated the same as the inanimate direct object referent in (11). Contrary to the accusative direct object bearing possessive suffixes, the ones in (11) and (12) are complemented by a personal pronoun expressing the number and person of the possessor. Concerning the information status of the direct object, it can be regarded as given and active, as the referent 'younger daughter' has been mentioned in the same sentence, although not in the reported speech part.

An additional example of possessive 1SG is provided in (13) because it illustrates an interesting combination of a direct object with a 1st person singular suffix, preceded by a personal pronoun expressing the person and number of the possessor but, here, it is also the argument of an imperative. 
(13) Central Selkup (ChDN_1983_GirlAndIce_flk.029)

mat midom tü to blekand onenže pireyend pende.

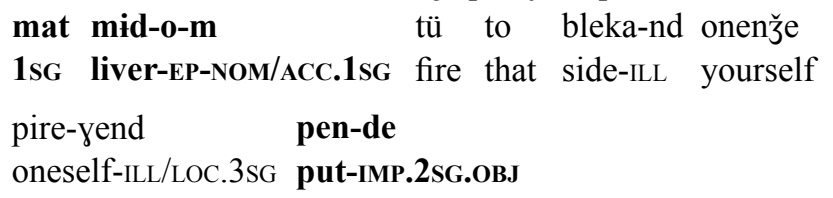

'Put my liver to that side of the fire, opposite from yourself.'

The other direct object that occurred next to an imperative was unmarked for case. Accordingly the form of $m \dot{i} d-o-m$ in (13) could be regarded a nominative with possessive suffix. The possessive function is emphasized/created by the personal pronoun accompanying the direct object. In Section 3.3, however, it is demonstrated that the imperative may not be as powerful as it seems.

\section{Discussion}

In their grammar of Southern Selkup, Bekker et al. (1995) name two cases for the marking of the direct object: accusative and nominative. Kuznecova et al. (1980) and Helimski (1998) conclude that accusative and nominative are used with regard to the definiteness of the direct object, verbal parameters, i.e. imperative mood, and the morphological form. Wickman (1955) postulates criteria for direct object marking taking into account imperative and quantification of the referent (see Section 1.3).

As to quantification, the present analysis could not confirm an impact on case marking. One instance involving the Russian lexeme wes' was found in nominative. However, counterexamples of direct objects supplemented by a numeral were consistently marked accusative.

Concerning the imperative mood as a condition for nominative marking, the examples from the corpus confirm an influence. This influence, however, is only true for nominal objects. Pronominal direct objects appear in accusative case nonetheless.

In regards of definiteness, there is no reliable account of definiteness in Central and Southern Selkup yet. Given the low number of nominative direct objects, however, a correlation seems unlikely. This could very well be the result of a process towards consistently accusative marked direct objects, but this will have to be further researched. 
Analyzing the information status, it appears that the bare nominal direct objects are all accessible, although with different sub-specifications, whereas the possessive nominal direct objects are given regardless of their case marking. The same holds true for pronominal direct objects. Pronominal direct objects are without exception in accusative.

Possessively marked direct objects occur in accusative as well as in nominative. Not always the possessive suffix has a possessive function, however. The possessive direct objects marked accusative receive a marking for 3rd person singular. Possessive direct objects in nominative behave differently. While accusative possessives were consistently marked $3 \mathrm{sG}$, the nominative possessives show different personal suffixes. One of the instances (example 9), was the direct object of an imperative, which accounts for the nominative marking. In another instance (example 10), the direct object was part of a coordination. It seems that the coordination of the direct object leads to nominative marking, as if with increasing complexity the case marking thrives towards simplification. This could also serve as an explanation for (3), where hurup 'wild animal' is part of a direct object phrase and marked nominative. The third group of possessive direct objects appears in 1st person singular with an ambiguous case marking. Accusative $-m$ and 1 st person singular - $m$ coincide thus making it impossible to decide for one form without the necessary contextual clues. Example (13) gives rise to the consideration that the $-m$ suffix may in fact be possessive only, as the direct object is the argument of an imperative and shows no difference in morphological form compared to the other instances. This account however conflicts with the observation made in (2) where a pronominal direct object remained in its accusative form despite the imperative. It may still be the case that the imperative required nominative case marking, but what is true for nominal direct objects may not correspond to pronominal ones.

From a typological point of view, Sinnemäki (2014) observed animacy, among others, to be an influencing factor for differential object marking. In this small corpus no differences in case marking could be attributed to the animacy of the direct object. Inanimate direct objects represented the majority of objects for nominal and pronominal objects as well. Animate direct objects, however, did not behave differently in terms of case marking.

With regard to dialectal differences, the data was not conclusive. In comparison with Northern Selkup the pattern for direct object marking seems a lot less clear. Between the two dialectal groups of Central and 
Southern Selkup we find a higher number of direct objects in Central Selkup. Differences in case marking strategy did not become apparent.

\section{Summary}

The present study is a small scale corpus analysis of six texts from the Central and Southern dialectal group of Selkup. The overall size of the corpus is 2225 tokens. Both dialectal groups are represented fairly equally. The corpus was analyzed with regard to case marking of direct objects. The vast majority of direct objects are marked accusative. Nonetheless, a number of objects occur in nominative. Special attention was paid to nominal direct objects and possessively marked direct objects in nominal and pronominal form. The pronominal direct objects are exclusively marked accusative. Nominal direct objects that receive nominative marking are often part of a complex construction such as a direct object phrase or a coordinated direct object. Concerning the possessively marked direct objects, again the majority are marked accusative. They show differences in the person of the possessor. Accusatives are marked with 3rd person singular and do not always have a strictly possessive function. Nominative possessive objects occur in 2 nd and 3rd person singular. The last group of possessive direct objects are forms marked with $-m$, which either stands for accusative, 1 st person singular or both. The context and the accompanying personal pronouns matching the person and number of the possessor identified the form as possessive. However, an accusative meaning or a syncretism of both cannot be discarded.

Among possible influencing factors for case marking, imperative mood proved to be a strong candidate, but only with nominal direct objects. Pronominal direct objects remain accusative even when they are the argument of an imperative. The information status of the possessive, nominal, and pronominal direct objects is mostly given. Only nominal non-possessive direct objects are accessible. Both parameters, imperative and information status provide grounds for further investigation. A study of a larger corpus bears the potential of revealing more influencing factors as well. 


\author{
Address: \\ Hannah Wegener \\ Universität Hamburg \\ Institut für Finnougristik/Uralistik \\ Überseering 35, Postfach \#29 \\ 22297 Hamburg, Germany \\ E-Mail: hannah.wegener@uni-hamburg.de
}

\title{
References
}

Aissen, Judith (2003) "Differential object marking: iconicity vs. economy". Natural Language \& Linguistic Theory 21, 435-483.

Bajdak, Aleksandra, Natal'ja Maksimova, and Nadežda Fedotova (2010) "Sel'kupskie teksty". In Andrey Filchenko, ed. Annotirovannye fol'klornye teksty obskoenisejskogo jazykovogo areala, 133-184. [Annotated folklore prose texts of the Ob-Yenisei language area.] Tomsk: Veter.

Bajdak, Aleksandra and Natal'ja Maksimova (2012) "Sel'kupskij tekst". In Andrey Filchenko, ed. Sbornik annotyrovannyx folklornyx i bytovyx tekstov obskoenisejskogo jazykovogo areala, 72-100. [Annotated folk and daily prose texts in the languages of the Ob-Yenisei language area.] Tomsk: Tomsk State Pedagogical University.

Bajdak, Aleksandra, Natal'ja Maksimova, Nadežda Fedotova and Sergej Kovylin (2013) "Sel'kupskie teksty". In Andrey Filchenko, ed. Sbornik annotirovannyx fol'klornyx i bytovyx tekstov obsko-enisejskogo jazykovogo areala, 153-201. [Annotated folk and daily prose texts in the languages of the Ob-Yenisei language area.] (Proceedings of the Department of Siberian Languages, 3.) Tomsk: Tomsk State Pedagogical University.

Bekker, Ėrika G., Larisa A. Alitkina, Valentina V. Bykonja, and Irina A. Il'jašenko (1995) Morfologija sel'kupskogo jazyka: južnye dialekty. Čast' 2. Tomsk: Tomsk State Pedagogical University.

Bossong, Georg (1985) Empirische Universalienforschung: differentielle Objektmarkierung in den neuiranischen Sprachen. (Ars linguistica, 14.) Tübingen: Narr.

Bykonja, Valentina, Natal'ja Kuznecova, and Natal'ja Maksimova (2005) Sel'kupskorusskij dialektnyj slovar'. Tomsk: Pedagogical State University.

Dalrymple, Mary and Irina Nikolaeva (2011) Objects and information structure. (Cambridge Studies in Linguistics, 131.) Cambridge: Cambridge University Press.

Gluškov, Sergej, Aleksandra Bajdak, and Natal'ja Maksimova (2013) "Dialekty sel'kupskogo jazyka”. In Natal'ja Tučkova, Sergej Gluškov, Elena Košeleva, Andrej Golovnjov, Aleksandra Bajdak, and Natal'ja Maksimova, eds. Sel'kupy: očerki tradicionnoj kul'tury i sel'kupskogo jazyka, 49-63. Tomsk: Tomsk Polytechnical University. 
Havas, Ferenc (2008) "Unmarked object in the Uralic languages: a diachronic typological approach". Linguistica Uralica 44, 1-33.

Helimski, Eugen (1998) "Selkup". In Daniel Abondolo, ed. The Uralic languages, 548-579. London: Routledge.

Helimski, Eugen and Imre Nagy (2004) “The Selkup language”. In György Nanovfszky, ed. The Finno-Ugric world, 271-272. Budapest: Teleki László Foundation.

Itkonen, Erkki (1972) "Über das Objekt in den finnisch-wolgaischen Sprachen". Finnisch-Ugrische Forschungen 39, 153-213.

Klumpp, Gerson (2014) "Identifiability, givenness and zero-marked referential objects in Komi”. Linguistics 52, 2, 415-444.

Kuznecova, Angelina, Evgenij Xelimskij, and Ekaterina Gruškina (1980) Očerki po sel'kupskomu jazyku. Tazovskij dialekt. Tom 1. Moskva: Moscow State University.

Lewy, Ernst (1933) “Zur Bezeichnung des Objektes im Mordwinischen”. In Liber Semisaecularis Societatis Fenno-Ugricae, 238-245. (Memoires de la Société FinnoOugrienne, 67.) Helsinki: Finno-Ugric Society.

Næss, Åshild (2004) "What markedness marks: the markedness problem with direct objects". Lingua 114, 1186-1212.

Sinnemäki, Kaius (2014) “A typological perspective on differential object marking”. Linguistics 52:2, 281-313.

Skribnik, Elena (2001) "Pragmatic structuring in Northern Mansi”. In Tõnu Seilenthal, ed. Congressus Nonus Internationalis Fenno-ugristarum. Pars IV: Dissertationes sectionum: Linguistica III, 222-239. Tartu: Tatu Ülikooli Kirjastu.

Virtanen, Susanna (2014) "Pragmatic direct object marking in Eastern Mansi". Linguistics 52:2, 391-413.

Wickman, Bo (1955) The form of the object in the Uralic languages. (Uppsala Universitets årsskrift, 6.) Uppsala: Lundequist.

\footnotetext{
Аннотация. Ханна Вегенер: О дифференцированном маркировании объекта в южном и центральном селькупском. Дифференциальное маркирование объекта было предметом исследования во многих языках мира. Такого рода исследования проводились как применительно к материалам отдельных языков, так и в типологическом аспекте. Дифференцированное маркирование объекта по сути является вариативностью в падежном оформлении объекта. Среди прочего на выбор падежа объекта влияют: одушевленность, коммуникативная структура предложения, модус и определенность. В настоящем исследовании данные центрального и южного селькупского исследуются с точки зрения падежного маркирования прямых объектов, выраженных именем существительным или местоимением. Объект, выраженный существительным, допускает аккузативное и номинативное оформление, в то время как объект, выраженный местоимением, последователен в использовании аккузатива. В процессе анализа возможных факторов было выявлено, что влияние оказывают повелительное наклонение, коммуникативный статус, а также структурные
} 
особенности объекта: является ли он частью большей группы или конструкции с однородными членами. Посессивные прямые объекты ведут себя похоже, поскольку предпочитают аккузативное оформление и лишь изредка номинативное. Однако в отличие от непосессивных объектов у них не наблюдалось вариативности в оформлении, обусловленной коммуникативной структурой.

Ключевые слова: падежное оформление актантов, дифференциальное маркирование объекта, уральские языки, самодийские языки, селькупский язык, синтаксис

Kokkuvõte. Hannah Wegener: Eristavast objektimarkeeringust lõuna- ja kesksölkupi keeltes. Eristava objektimarkeeringu nähtust on uuritud hulgas maailma keeltes. Uurimusi on läbi viidud nii üksikute keelte tasandil kui ka tüpoloogilisest vaatenurgast. Üldiselt kirjeldatakse eristavat objektimarkeeringut kui osasihitise käände varieerumist. Faktorid, mis variatsiooni põhjustavad, on muuhulgas viidatava elusus, infostruktuur, kõneviis, ja definiitsus. Selles uurimuses vaadeldakse kesk- ja lõunasölkupi keelematerjali pidades silmas käänd- ja asesõnaliste täissihitiste käändeid. Käändsõnalised täissihitised esinevad akusatiivis ja nominatiivis, samas kui asesõnalised täissihitised on järjepidevalt akusatiivis. Uurides erinevat käändevalikut põhjustavaid faktoreid, näib käskival kõneviisil olevat mõju nii infostruktuurile kui ka sihitise struktuurilistele omadustele, st kas see on osa sihitis-fraasist või koordinatsioonist. Possessiivsed täissihitised käituvad sarnaselt ja esinevad peamiselt akusatiivis ning vaid üksikutel juhtudel ka nominatiivis. Vastupidiselt mittepossessiivsetele täissihitistele ei ilmne siin infostaatuse variatsioone.

Märksõnad: argumendimarkeering, eristav objektimarkeering, uurali keeled, samojeedi keeled, sölkup, süntaks 